\title{
Yeast Cell as a Bio-Model for Measuring the Toxicity of Fish-Killing Flagellates
}

\author{
Malihe Mehdizadeh Allaf ${ }^{1}$ and Charles G. Trick ${ }^{1,2, *}$ \\ 1 Department of Biology, Western University, London, ON N6A 5B7, Canada; mmehdiz@uwo.ca \\ 2 Interfaculty Program in Public Health, Schulich School of Medicine and Dentistry, Western University, \\ London, ON N6G 2M1, Canada \\ * Correspondence: trick@uwo.ca; Tel.: +1-(306)-251-2954
}

check for updates

Citation: Allaf, M.M.; Trick, C.G. Yeast Cell as a Bio-Model for Measuring the Toxicity of Fish-Killing Flagellates. Toxins 2021, 13, 821 . https://doi.org/10.3390/ toxins13110821

Received: 29 August 2021

Accepted: 16 November 2021

Published: 21 November 2021

Publisher's Note: MDPI stays neutral with regard to jurisdictional claims in published maps and institutional affiliations.

\begin{abstract}
Harmful algal blooms are a significant environmental problem. Cells that bloom are often associated with intercellular or dissolved toxins that are a grave concern to humans. However, cells may also excrete compounds that are beneficial to their competition, allowing the cells to establish or maintain cells in bloom conditions. Here, we develop a yeast cell assay to assess whether the bloom-forming species can change the toxicity of the water environment. The current methods of assessing toxicity involve whole organisms. Here, yeast cells are used as a bioassay model to evaluate eukaryotic cell toxicity. Yeast is a commonly used, easy to maintain bioassay species that is free from ethical concerns, yet is sensitive to a wide array of metabolic and membrane-modulating agents. Compared to methods in which the whole organism is used, this method offers rapid and convenient cytotoxicity measurements using a lower volume of samples. The flow cytometer was employed in this toxicology assessment to measure the number of dead cells using alive/dead stain analysis. The results show that yeast cells were metabolically damaged after $1 \mathrm{~h}$ of exposure to our model toxin-producing euryhaline flagellates (Heterosigma akashiwo and Prymnesium paroum) cells or extracts. This amount was increased by extending the incubation time.
\end{abstract}

Keywords: bioassay; yeast; harmful algal blooms; Heterosigma akashiwo; Prymnesium parvum

Key Contribution: 1. The fish-killing activities of harmful algae are notoriously difficult to assess, as neither the structures nor modes of action are uniform. 2. Using whole organism or cell-lines as bioassay targets provides a great improvement, but these methods are costly and require a significant level of technical skill. 3. A yeast bioassay model provides an alternative while remaining true to the whole-organism bioassay.

\section{Introduction}

Harmful algal blooms (HABs) are a major universal threat due to their significant impact on ecosystems, public health, tourism, and fisheries [1]. The frequency of HABs has increased in recent decades as a result of climate change, and cultural eutrophication caused by domestic, industrial, and agricultural waste [2-4]. Among the different phytoplankton species responsible for the formation of HABs, flagellate species represent $90 \%$ and dinoflagellates represent 75\% (45-60 taxa) [5].

The harmful species' mechanisms, which can cause mortality or physiological impairment, can be divided into two general types: mechanical and physical damage, and chemical damage [6]. A non-toxic bloom-forming algal species accumulates a high biomass and results in surface water discoloration, which kills both fish and invertebrates due to oxygen depletion or starvation $[2,3,6]$. The oxygen depletion may be caused by the high respiration rate of algae during night or in dim light during the day, or by bacteria during the decay of the bloom [2]. Chemical damage happens through the production of potent toxins, which can accumulate or transfer through the food chain to humans via shellfish and 
fish consumption [2,7-9]. The toxin can cause gastrointestinal and neurological illnesses, such as paralytic shellfish poisoning (PSP) [8,9], diarrhetic shellfish poisoning (DSP) [2,4], amnesic shellfish poisoning (ASP) [2,3], ciguatera fish food poisoning [10] and neurotoxic shellfish poisoning (NSP) [9].

There are also a limited number of species with $\mathrm{HAB}$ attributes that are particularly damaging to fish and invertebrates and, therefore, can cause great economic losses. Genera Prymnesium, Chrysochromulina, and Phaeocystis from prymnesiophytes and Chattonella, Heterosigma, and Fibrocapsa from raphidophytes belong to this category [11].

Heterosigma akashiwo and Prymnesium parvum are two golden-brown flagellate species from the raphidophyte and prymnesiophyte classes, respectively. These two active fishkillers have the high potential to kill thousands or even millions of fish per bloom. The blooms of $H$. akashiwo are sporadic and have been reported in Canada and the United States [12-15], Mexico [16], Japan [17,18], Chile [19], China [20], New Zealand [21], and Norway [22]. However, the blooms of P. parvum, widely distributed throughout temperate regions, have frequently been reported in Israel [23] England [24], Norway [25], China [26], Tunis [27], and United States [28]. Although these two species are taxonomically separated from each other, they apparently kill fish in a similar fashion.

The toxicity mechanisms of these types of flagellates are controversial and unresolved. Scientists have suggested the following mechanisms are active procedures that kill fish: (a) mucus secretion causes fish asphyxiation by covering the gill cells [21], (b) neurotoxins or cardiotoxins result in respiratory and/or cardiac paralysis [17,29], (c) reactive oxygen species (ROS) production alters gill structure and function [3,30,31], and (d) hemolysis compounds cause blood cell lysis [2,32,33].

To measure the ichthyotoxic effect of these flagellates, the most common bioassay is to use different fish strains or species with different ages (larvae, juveniles, or adults), and varying exposure times. Some of the routinely used species are brine shrimp; Artemia salina [34-36], Japanese sea bream, Pagrus major [17,37-39], and yellowtail, Seriola guinqueradiata [40-42]. Using mice as a bioassay models has been debatable since they were first used, due to unreliability and the associated ethical issues [43,44]. Various cell lines obtained from different animals including a mouse [45], a rat [34], fish gill cells [46-49], or human tissues such as human hepatoma cell line (HepG2) [50], or human colon carcinoma cell line (Caco-2) [51], are recommended and have been used to measure different types of toxins produced by algal bloom species. Using whole organisms or their cell lines as a bioassay model for ichthyotoxicity measurement obligates prolonged exposure or follow-up periods, and therefore increases the errors in evaluation. Furthermore, the high cost of these types of bioassays is a serious concern [35,52]. Therefore, finding a biological cell model to measure the cytotoxins in a reliable, fast, and inexpensive manner would be very beneficial and highly sought-after.

To that purpose this study has proposed the use of yeast cells (Saccharomyces cerevisiae), which are widely used as eukaryotic model organisms [53]. The culturing and maintenance of Saccharomyces cerevisiae is simple and rapid, and is also free of any ethical objections. In addition, Saccharomyces cerevisiae is sensitive to a broad range of toxic substances and economically affordable [54].

\section{Results}

After measuring the percentage of dead yeast cells in the presence of two different fishkilling flagellates; H. akashiwo and P. parvum; the results revealed that the toxicity effect of these two strains was improved by rupturing the cells using sonication and centrifugation techniques (Figure 1). In H. akashiwo, the highest level of toxicity was observed in sample G, which was obtained by sonicating the pellets after centrifugation and an additional sonication step were conducted (Figure 1). The yeast mortality was about $37 \%$ after an hour, which increased to $62 \%$ after $3 \mathrm{~h}$ of incubation. At that stage, the highest level of toxicity in this flagellate belonged to samples I (sonicated pellets after one more centrifugation and sonication step), D (sonicated pellets) and E (supernatant after one sonication and 
centrifugation step). These fractionated samples killed almost $30 \%$ of yeast cells after one hour of exposure. Increasing the incubation time from $1 \mathrm{~h}$ to $3 \mathrm{~h}$ displayed a significant effect on the mortality of the yeast cells $(p<0.001)$ (Table 1). Moreover, a significant difference in yeast mortality was observed between the control and different treatments $(p<0.001)$. The positive control was prepared by sonicating the yeast cells at a continuous output of nine for a minute and the negative control was prepared by mixing yeast cells with artificial sea water (ASW). Sample G shows a significant difference compared to other treatments, while there was no significant difference between I, D and E.
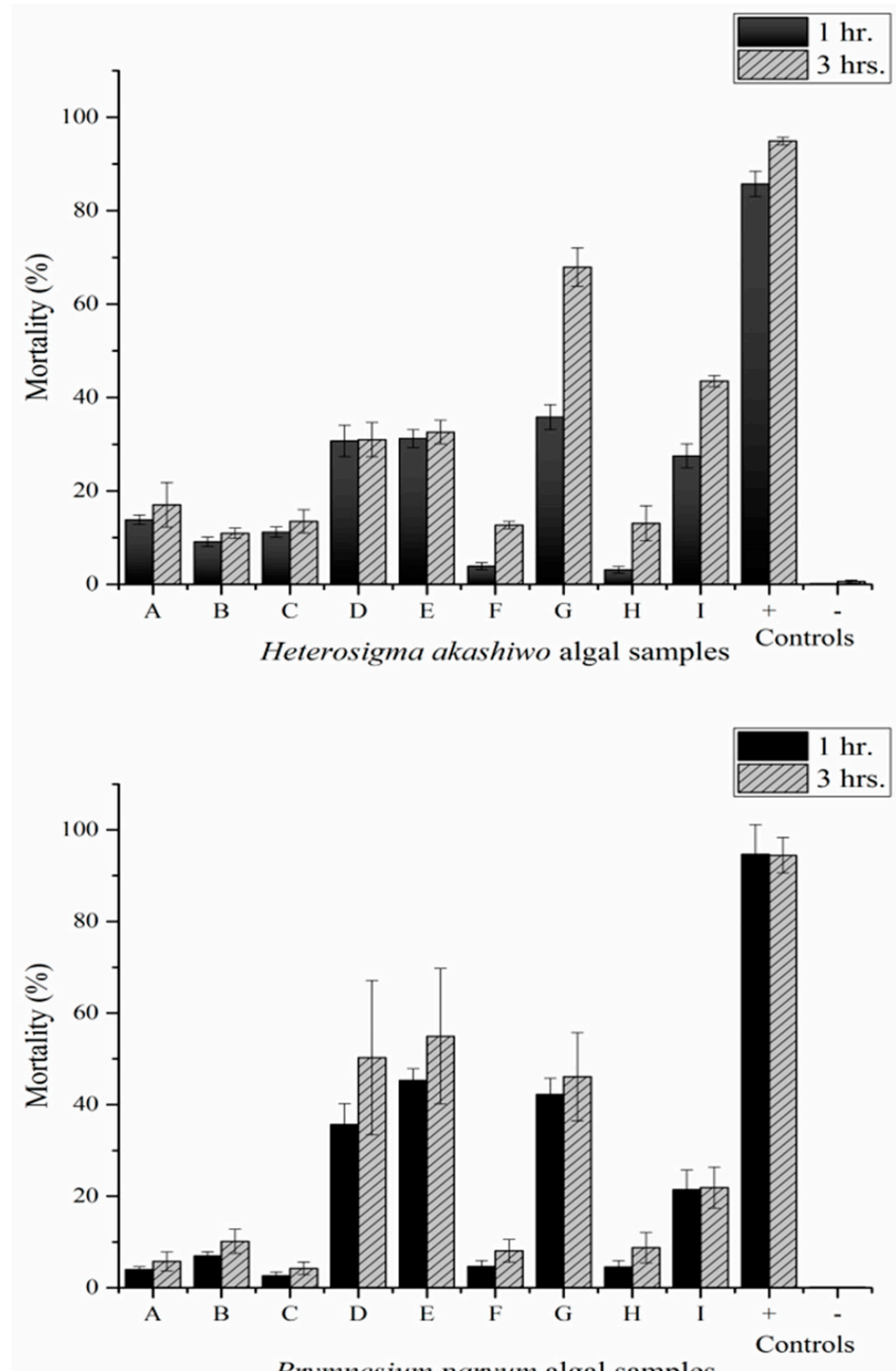

Figure 1. Yeast mortality (\%) after exposure to different sample treatments of H. akashiwo and $P$. parvum $(\mathrm{n}=3 \pm \mathrm{SD})$. 
Table 1. Two-way analysis of variance (ANOVA) for H. akashiwo and P. parvum toxicity measurement.

\begin{tabular}{|c|c|c|c|c|c|c|c|}
\hline Algae & Source & Remark & $\begin{array}{l}\text { Sum of } \\
\text { Squares }\end{array}$ & $\begin{array}{l}\text { Degree of } \\
\text { Freedom }\end{array}$ & $\begin{array}{l}\text { Mean } \\
\text { Square }\end{array}$ & f-Value & $p$-Value \\
\hline \multirow{4}{*}{$\begin{array}{c}\text { Heterosigma } \\
\text { akashiwo }\end{array}$} & Time & ${ }^{\dagger}$ Sig. & 994.76 & 1 & 994.76 & 56.21 & $<0.001$ \\
\hline & $\S$ Treat. & Sig. & $40,758.84$ & 10 & 4075.88 & 230.29 & $<0.001$ \\
\hline & Time $\times$ Treat & Sig. & 1358.04 & 10 & 135.80 & 7.67 & $<0.001$ \\
\hline & Residual & & 778.75 & 44 & 17.7 & & \\
\hline \multirow{4}{*}{$\begin{array}{l}\text { Prymnesium } \\
\text { parvum }\end{array}$} & Time & Sig. & 247.58 & 1 & 247.58 & 6.37 & 0.015 \\
\hline & Treat. & Sig. & $51,661.38$ & 10 & 5166.14 & 132.85 & $<0.001$ \\
\hline & Time $\times$ Treat & $\ddagger$ N-Sig & 302.93 & 10 & 30.29 & 0.78 & 0.648 \\
\hline & Residual & & 1711.04 & 44 & 38.89 & & \\
\hline
\end{tabular}

${ }^{\dagger}$ Sig = Significant $;{ }^{\ddagger}$ N-Sig = Non-significant; ${ }^{\S}$ Treat. $=$ Treatment.

The highest levels of toxicity in P. paroum were detected in the sample treatments of E, D and G, respectively, while there was a significant difference between these sample treatments and the rest of samples $(p<0.001)$. The yeast mortality was more than $35 \%$ in this treatment after one hour, which was amplified to almost $50 \%$ after $3 \mathrm{~h}$ of incubation. Furthermore, the yeast mortality showed a significant effect between positive control and different algal samples $(p<0.001)$. The two-way ANOVA parameters for both species are presented in Table 1.

Among the four highest treatments (D, E, G, I), between H. akashiwo and P. parvum, no significant difference was observed (Figure 2). However, a significant difference was detected among different treatments $(p<0.005)$. Sample $G$, prepared from H. akashiwo, was significantly different from D, E and I, while sample I, prepared from P. parvum, showed the highest difference compared with sample D and E. Samples D and E in P. parvum showed more toxicity compared to H. akashiwo, while this was vice versa for the other two treatments. There was also a statistically significant difference in interaction between algal species and the four treatments $(p=0.001)$ (Table 2).

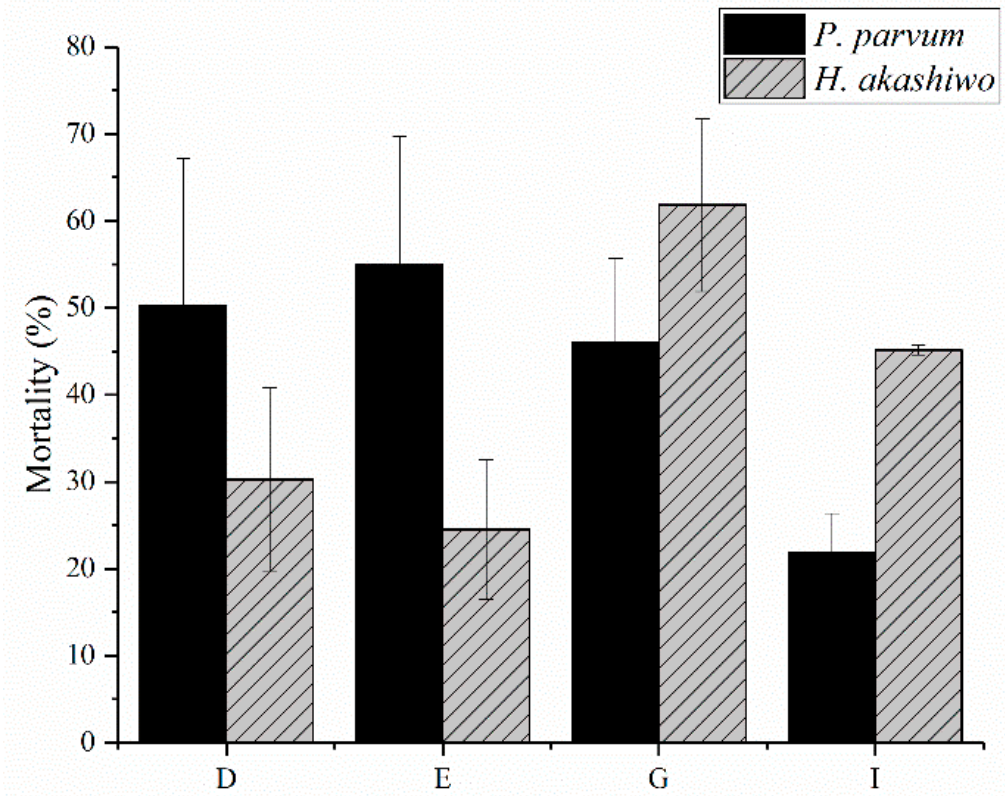

Algal samples

Figure 2. Comparison between highest yeast mortality (\%) in the presence of $H$. akashiwo and $P$. parvum after $3 \mathrm{~h}$ incubation. 
Table 2. Two-way analysis of variance (ANOVA) of the four highest effective treatments of H. akashiwo and P. parvum.

\begin{tabular}{|c|c|c|c|c|c|c|}
\hline Source & Remark & $\begin{array}{l}\text { Sum of } \\
\text { Squares }\end{array}$ & $\begin{array}{l}\text { Degree of } \\
\text { Freedom }\end{array}$ & Mean Square & f-Value & $p$-Value \\
\hline${ }^{\dagger}$ Algal species & Nonsignificant & 1.397 & 1 & 1.397 & 0.0130 & 0.911 \\
\hline ** Treatment & Significant & 1840.645 & 3 & 613.548 & 5.697 & 0.008 \\
\hline Algal species $\times$ Treatment & Significant & 2721.014 & 3 & 907.005 & 8.422 & 0.001 \\
\hline Residual & & 1723.203 & 16 & 107.700 & & \\
\hline
\end{tabular}

${ }^{\dagger}$ Algal species = Heterosigma akashiwo and Prymnesium parvum. ${ }^{* *}$ Treatments = Sample D, E, G, I.

To validate the data Tetraselmis chuii, a nontoxic marine species, were used in this study (data not shown). Additionally, the effect of salinity and temperature on the mortality of $S$. cerevisiae was measured (unpublished data).

\section{Discussion}

Measuring the level of toxicity in fish-killing flagellates is a complicated process, and not a single standard has been used by the researchers. The floating carcasses of caged fish, or the embayment of fish in the bloom regions, are the commonly accepted signs of the presence of harmful algal blooms. The toxin mechanism framework for fish-killing flagellates such as $H$. akashiwo and $P$. parvum is the production of excessive mucus by microalgae [21], production of brevetoxin-like compounds [17,29], the ability to produce and excrete reactive oxygen species (ROS) [30,31,49], and the production of hemolytic compounds [33].

Alternate approaches that correlate with the production of toxicity have been used by researchers. Some alternate methods for toxicity measurement use a whole organism or larva, hemolytic activity, neurological damage using zebra fish embryos, gill cell degeneration, and cellular permeability. In this study, we propose yeast as a bio- model to measure toxicity in fish-killing flagellates. This method has many benefits over traditional methods. This method is fast and reliable, inexpensive, many samples can be tested in a short period of time, and a small volume of samples is required.

The present study demonstrates that yeast cells can be used as a biological cell model to measure the toxicity of harmful algal species such as H. akashiwo and P. parvum. The obtained data also revealed that the toxin produced by the aforementioned species was released upon the cell damage of both species. Thus, the suggestion is that the toxic compounds are within certain intracellular compartments, and leakage or release of these compounds from $H$. akashiwo and P. parvum cells is enhanced by the breaking of cells. Among different treatments that were proposed in this study, samples D, E, G, and I showed the highest level of yeast mortality.

Similar results were observed for the same species or similar ones using other toxicity measurements. Kuroda et al. [55] stated that the ruptured cell suspension of Chattonella marina produced strong hemolytic activity towards rabbit erythrocytes; however, either intact cell suspension or the cell-free culture supernatant did not express any hemolytic activity. The same results were obtained for the extracts of various Fibrocapsa japonica strains collected worldwide [56]. Ling and Trick [33] reported that after they fractioned the H. akashiwo cells, cell hemolytic activity improved in comparison with the intact cells. Their data indicated that the hemolytic agents were released upon the cell damage of H. akashiwo by employing sonication or centrifugation.

Mohamed and Sheheri [36] used aqueous and methanol extracts of H. akashiwo to expose to nauplii of $48 \mathrm{~h}$ hatched cysts of Artemia salina and reported the mortality after $48 \mathrm{~h}$ of incubation. Both samples were toxic towards A. salina; however, the methanol extracts were more toxic. The same results were also observed for hemolytic activity.

Segar et al. [57] studied the effect of nutrient repletion on the toxicity of P. parvum. They observed that lysing P. parvum cells through sonication significantly decreased the viability of gill cells and improved the toxicity level of this species in comparison with live cultures. 
Our results agree with previous research studies in this field. Our findings suggest that a toxin, or toxins, are kept within cellular compartments of the cells and therefore cellular membrane damage can facilitate and enhance a toxin release from fish-killing species.

Employing this method will allow us to measure the toxicity effect of fish-killing flagellates in a fast and reliable method, while saving time, resources, and money, all of which are crucial to the environment, aquaculture facilities, and public health.

\section{Conclusions}

The fundamental purpose of this research was to find a fast, reliable, and inexpensive method of measuring and evaluating the levels of toxicity within different strains of algal bloom forming species. For this purpose, a yeast cell was recommended for use as a bio-model since they are free of ethical concerns, are sensitive to a range of various toxic elements, are low-cost, and are simple to work with and maintain within a short time span. Performing this assay requires a low volume of samples. In addition, using a flow cytometry technique for measuring the viability of the cells quickens the toxicity measurement process.

The obtained data revealed that breaking the toxic algal cells improved the ichthyotoxic effect of these microorganisms, which means the toxin is located inside the cellular compartments. Sample D, E, G, and I, for both species, showed the highest level of yeast cell mortality. Moreover, the results of the two fish-killing species, with different taxonomic groups, are similar.

Saccharomyces includes various species with a similar morphology and the potential to be used as a cell bio-model for measuring toxicity, although further investigation is required.

\section{Materials and Methods}

A non-axenic strain of Heterosigma akashiwo (NWFSC-513), isolated in 2010 from Clam Bay, WA, USA, and Prymnesium paroum (UTEX LB 2827) isolated near Charleston, SC, USA in 2002 and purchased from the UTEX collection (University of Texas at Austin, Austin, TX, USA), were used in this study.

The stock cultures for $H$. akashiwo and P. paroum were maintained in $\mathrm{f} / 2$ and $\mathrm{f} / 20$ (minus Si) medium [58], respectively, complemented by artificial seawater medium (ESAW) [59]. The cultures were grown in a $250 \mathrm{~mL}$ Erlenmeyer flask at $20 \pm 1^{\circ} \mathrm{C}$ and under a continuous white fluorescent light intensity of $80 \pm 5 \mu \mathrm{mol}$ photons $\mathrm{m}^{-2} \mathrm{~s}^{-1}$.

Saccharomyces cerevisiae was grown for $15 \pm 1 \mathrm{~h}$ at room temperature in YPD medium ( $1 \%$ yeast extract, $2 \%$ peptone, $2 \%$ dextrose, $2 \%$ agar (all $w / v)$ ).

To measure the toxicity of both strains, algal samples were prepared from exponentially growing cultures (4-5 days after inoculation). All samples and experiments were performed in triplicate. The data were presented as an average value \pm standard deviations. The algal treatment samples were prepared as follows:

- $\quad$ Sample A: Intact cells (viable cells and extracellular material) of both species.

- Sample B: Ultrasonic rupture cells suspensions, which were obtained by sonicating $7 \mathrm{~mL}$ culture suspensions in an ice bath with a continuous output power of 9 for $1 \mathrm{~min}$ with a Virsonic 100 Ultrasonic Cell Disrupter (VirTis Company, Gardiner, NY, USA).

- $\quad$ Sample C: culture supernatants were prepared by centrifuging a $7 \mathrm{~mL}$ sample A at $500 \times g$ for $10 \mathrm{~min}$ at $4{ }^{\circ} \mathrm{C}$, using $15 \mathrm{~mL}$ falcon centrifuge tubes in a Beckman GH-3.8/GH-3.8A swing-out rotor (Beckman Coulter, Fullerton, CA, USA).

- Sample D: resuspended pellets in ASW and sonicated for $1 \mathrm{~min}$ with a continuous output power of 9 .

- $\quad$ Sample E: Sample D supernatants, were prepared by centrifuging sample D at $6100 \times g$ for $15 \mathrm{~min}$ at $4^{\circ} \mathrm{C}$.

- $\quad$ Sample F: Sample B supernatants, were obtained by centrifuging sample B at $500 \times g$ for $10 \mathrm{~min}$ at $4^{\circ} \mathrm{C}$. 
- $\quad$ Sample G: resuspended pellets from sample B and sonicated with similar output power for sample B and D.

- Sample H: Sample F supernatants, were attained by centrifuging at $6100 \times g$ for $15 \mathrm{~min}$ at $4{ }^{\circ} \mathrm{C}$.

- $\quad$ Sample I: resuspended, sonicated pellets from sample F, with similar power for pervious samples.

- Negative control was prepared by mixing yeast with ASW.

- Positive control was prepared by sonicating the yeast sample for 1 min with a continuous output power of 9 .

The algal sample preparation procedure is outlined in Figure 3. To measure toxicity, the prepared algal samples were combined with the yeast cells with a ratio of 5 to 1 and incubated for 1 and $3 \mathrm{~h}$ at room temperature. To measure the number of cells and fluorescence intensity, a Turner Designs PhytoCyt flow cytometer (Sunnyvale, CA, USA) was used. To measure the background, the samples were run without dye. Then, $15 \mathrm{~min}$ before toxicity measurement, a final concentration of $1.5 \mu \mathrm{M}$ SYTOX ${ }^{\circledR}$ Green (Life Technologies, Carlsbad, CA, USA), a high-affinity nucleic acid stain that permeates into the cells with compromised plasma membranes [60], was added to measure the cell integrity and the percentage of dead cells. The fluorochrome SYTOX ${ }^{\circledR}$ Green was employed to estimate the degree of cell membrane permeability of yeast during treatments. The highest toxicity should be expressed in samples when the cells are most permeable, as indicated by the greatest level of SYTOX ${ }^{\circledR}$ Green fluorescence per cell.

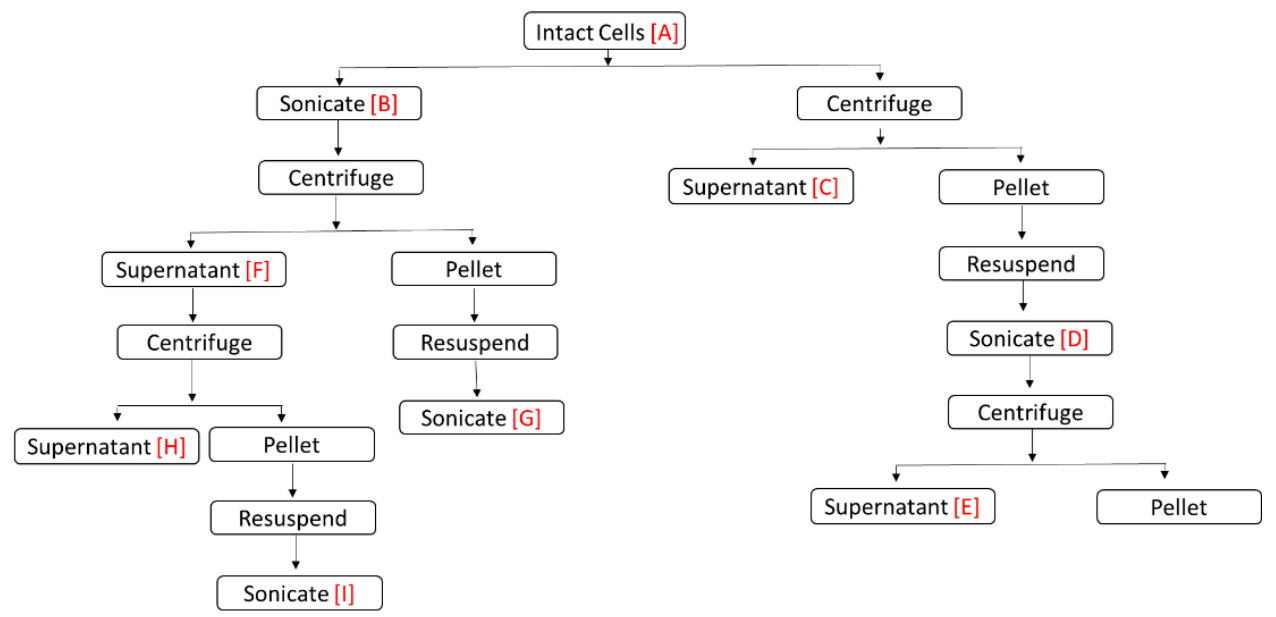

Figure 3. Summary of algal samples preparation.

To determine the live/dead cells using SYTOX ${ }^{\circledR}$ Green fluorescence dye, CFlow ${ }^{\circledR}$ Plus software, version 1.0.227.5 was used. A bivariate scatter plot with green versus chlorophyll a fluorescence detectors was applied. The plot was divided into four quadrants where the unstained cell population was placed in the lower left quadrant, while the stained cell population, which represented the dead or compromised cells, was in the upper right quadrant.

Statistical analysis: Data reporting the percentage of dead yeast cells are expressed as mean $\pm \mathrm{SD}(\mathrm{n}=3)$. The data were compared using a two-way analysis of variance (ANOVA) followed by Tukey multiple comparison tests analyzed by SigmaPlot 12.0. A significance level of $95 \%(\alpha=0.05)$ was considered for all statistical analyses.

Author Contributions: This research is part of a Ph.D. thesis of M.M.A., C.G.T. served as the supervisor. C.G.T. and M.M.A. conceptualized the project and worked together for analysis and writing the manuscript. M.M.A. was responsible for methodology development, the investigation process, data quality assessment, and original draft preparation. All authors have read and agreed to the published version of the manuscript. 
Funding: This work was funded by NSERC Discovery Grant 4458-2016 to CGT, and an NSERC CREATE Algal Bloom Abatement through Technology and Education (ABATE) (448172-2014) awarded to Irena Creed (Western University) and CGT.

Institutional Review Board Statement: Not applicable.

Informed Consent Statement: Not applicable.

Data Availability Statement: There is no supporting data of this paper.

Conflicts of Interest: The authors declare no conflict of interest.

\section{References}

1. Anderson, D.M.; Cembella, A.D.; Hallegraeff, G.M. Progress in Understanding Harmful Algal Blooms: Paradigm Shifts and New Technologies for Research, Monitoring, and Management. Annu. Rev. Mar. Sci. 2012, 4, 143-176. [CrossRef]

2. Hallegraeff, G.M. A review of harmful algal blooms and their apparent global increase. Phycologia 1993, 32, 79-99. [CrossRef]

3. Hallegraeff, G.M. Ocean Climate change, phytoplankton community responses, and harmful algal blooms: A formidable predictive challenge. J. Phycol. 2010, 46, 220-235. [CrossRef]

4. Wells, M.L.; Trainer, V.L.; Smayda, T.J.; Karlson, B.S.; Trick, C.G.; Kudela, R.M.; Ishikawa, A.; Bernard, S.; Wulff, A.; Anderson, D.M.; et al. Harmful algal blooms and climate change: Learning from the past and present to forecast the future. Harmful Algae 2015, 49, 68-93. [CrossRef] [PubMed]

5. Smayda, T.J. Harmful algal blooms: Their ecophysiology and general relevance to phytoplankton blooms in the sea. Limnol. Oceanogr. 1997, 42, 1137-1153. [CrossRef]

6. Smayda, T.J. What is a bloom? A commentary. Limnol. Oceanogr. 1997, 42, 1132-1136. [CrossRef]

7. Backer, L.C.; Schurz-Rogers, H.; Fleming, L.E.; Kirkpatrick, B.; Benson, J. Marine phycotoxins in seafood. In Toxins in Food; Dabrowski, W.M., Sikorski, Z.E., Eds.; CRC Press LLC: Boca Raton, FL, USA, 2005; pp. 155-190.

8. Isbister, G.K.; Kiernan, M.C. Neurotoxic marine poisoning. Lancet Neurol. 2005, 4, 219-228. [CrossRef]

9. Watkins, S.M. Neurotoxic Shellfish Poisoning. Mar. Drugs 2008, 6, 430-455. [CrossRef] [PubMed]

10. Achaibar, K.C.; Moore, S.; Bain, P.G. Ciguatera poisoning. Pract. Neurol. 2007, 7, 316-322. [CrossRef] [PubMed]

11. Edvardsen, B.; Imai, I. The ecology of harmful flagellates within Prymnesiophyceae and Raphidophyceae. In Ecology of Harmful Algae, Ecological Studies: Analysis and Synthesis; Graneli, E., Turner, J.T., Eds.; Springer: Berlin/Heidelberg, Germany, 2006; Volume 189, pp. 67-79.

12. Hershberger, P.K.; Rensel, J.E.; Matter, A.L.; Taub, F. Vertical distribution of the chloromonad flagellate Heterosigma carterae in columns: Implications for bloom development. Can. J. Fish. Aquat. Sci. 1997, 54, 2228-2234. [CrossRef]

13. Rensel, J.E.; Whyte, J.N.C. Finfish mariculture and harmful algal blooms. In Manual on Harmful Marine Microalgae. Monographs on Oceanographic Methodology; Hallegraeff, G.M., Anderson, D.M., Cembella, A.D., Eds.; UNESCO Publishing: Paris, France, 2003; Volume 11, pp. 693-722.

14. O'Halloran, C.; Silver, M.W.; Holman, T.R.; Scholin, C.A. Heterosigma akashiwo in central California waters. Harmful Algae 2006, 5, 124-132. [CrossRef]

15. Rensel, J.J.; Haigh, N.; Tynan, T.J. Fraser river sockeye salmon marine survival decline and harmful blooms of Heterosigma akashiwo. Harmful Algae 2010, 10, 98-115. [CrossRef]

16. Livingston, R.J. Phytoplankton bloom effects on a gulf estuary: Water quality changes and biological response. Ecol. Appl. 2007, 17, S110-S128. [CrossRef]

17. Ono, K.; Khan, S.; Onoue, Y. Effects of temperature and light intensity on the growth and toxicity of Heterosigma akashiwo (Raphidophyceae). Aquac. Res. 2000, 31, 427-433. [CrossRef]

18. Haque, S.M.; Onoue, Y. Effects of salinity on growth and toxin production of a noxious phytoflagellate, Heterosigma akashiwo (Raphidophyceae). Bot. Mar. 2002, 45, 356-363. [CrossRef]

19. Clement, A.; Lembeye, G. Phytoplankton monitoring program in the fish farming region of South Chile. In Toxic Phytoplankton Blooms in the Sea, Proceedings of the Fifth International Conference on Toxic Marine Phytoplankton, Newport, RI, USA, 28 October-1 November 1991; Developments in Marine Biology; Smayda, T.J., Shimizu, Y., Eds.; Elsevier: New York, NY, USA, 1993; Volume 3 , pp. 223-228.

20. Tseng, C.K.; Zhou, M.J.; Zou, J.Z. Toxic phytoplankton studies in China. In Toxic Phytoplankton Blooms in the Sea, Proceedings of the Fifth International Conference on Toxic Marine Phytoplankton, Newport, RI, USA, 28 October-1 November 1991; Developments in Marine Biology; Smayda, T.J., Shimizu, Y., Eds.; Elsevier: New York, NY, USA, 1993; Volume 3, pp. $347-352$.

21. Chang, F.H.; Anderson, C.; Boustead, N.C. First record of a Heterosigma (Raphidophyceae) bloom with associated mortality of cage-reared salmon in Big Glory Bay, New Zealand. N. Z. J. Mar. Freshw. Res. 1990, 24, 461-469. [CrossRef]

22. Pettersson, L.H.; Pozdnyakov, D. Qualification, species variety, and consequences of harmful algal blooms (HABs). In Monitoring of Harmful Algal Blooms; Springer: Singapore, 2013; pp. 1-24.

23. Ulitzur, S.; Shilo, M. Mode of Action of Prymnesium parvum Ichthyotoxin. J. Protozool. 1966, 13, 332-336. [CrossRef]

24. Holdway, P.A.; Watson, R.A.; Moss, B. Aspects of the ecology of Prymnesium parvum (Haptophyta) and water chemistry in the Norfolk Broads, England. Freshw. Biol. 1978, 8, 295-311. [CrossRef] 
25. Kaartvedt, S.; Johnsen, T.M.; Aksnes, D.L.; Lie, U.; Svendsen, H. Occurrence of the Toxic Phytoflagellate prymnesium parvum and Associated Fish Mortality in a Norwegian Fjord System. Can. J. Fish. Aquat. Sci. 1991, 48, 2316-2323. [CrossRef]

26. Guo, M.; Harrison, P.J.; Taylor, F.J.R. Fish kills related to Prymnesium parvum N. Carter (Haptophyta) in the People's Republic of China. Environ. Biol. Fishes 1996, 8, 111-117. [CrossRef]

27. Probert, I.; Fresnel, J. Prymnesium lepailleuriisp. nov. (Prymnesiophyceae), a new littoral flagellate from the Mediterranean Sea. Eur. J. Phycol. 2007, 42, 289-294. [CrossRef]

28. Roelke, D.L.; Grover, J.P.; Brooks, B.W.; Glass, J.; Buzan, D.; Southard, G.M.; Fries, L.; Gable, G.M.; Schwierzke-Wade, L.; Byrd, M.; et al. A decade of fish-killing Prymnesium parvum blooms in Texas: Roles of inflow and salinity. J. Plankton Res. 2011, 33, $243-253$. [CrossRef]

29. Khan, S.; Arakawa, O.; Onoue, Y. Neurotoxins in a toxic red tide of Heterosigma akashiwo (Raphidophyceae) in Kagoshima Bay, Japan. Aquac. Res. 1997, 28, 9-14. [CrossRef]

30. Yang, C.; Albright, L.; Yousif, A. Oxygen-radical-mediated effects of the toxic phytoplankter Heterosigma carterae on juvenile rainbow trout Oncorhynchus mykiss. Dis. Aquat. Org. 1995, 23, 101-108. [CrossRef]

31. Twiner, M.J. Possible physiological mechanisms for production of hydrogen peroxide by the ichthyotoxic flagellate Heterosigma akashiwo. J. Plankton Res. 2000, 22, 1961-1975. [CrossRef]

32. Neely, T.; Campbell, L. A modified assay to determine hemolytic toxin variability among Karenia clones isolated from the Gulf of Mexico. Harmful Algae 2006, 5, 592-598. [CrossRef]

33. Ling, C.; Trick, C.G. Expression and standardized measurement of hemolytic activity in Heterosigma akashiwo. Harmful Algae 2010, 9, 522-529. [CrossRef]

34. Astuya-Villalón, A.; Ramírez, A.E.; Aballay, A.; Araya, J.; Silva, J.; Ulloa, V.; Fuentealba, J. Neurotoxin-like compounds from the ichthyotoxic red tide alga Heterosigma akashiwo induce a TTX-like synaptic silencing in mammalian neurons. Harmful Algae 2015, 47, 1-8. [CrossRef]

35. Powers, L.; Creed, I.F.; Trick, C.G. Sinking of Heterosigma akashiwo results in increased toxicity of this harmful algal bloom species. Harmful Algae 2012, 13, 95-104. [CrossRef]

36. Mohamed, Z.A.; Al-Shehri, A.M. The link between shrimp farm runoff and blooms of toxic Heterosigma akashiwo in Red Sea coastal waters. Oceanology 2012, 54, 287-309. [CrossRef]

37. Endo, M.; Foscarini, R.; Kuroki, A. Electrocardiogram of a marine fish, Pagrus major, exposed to red tide plankton, Chattonella marina. Mar. Biol. 1988, 97, 477-481. [CrossRef]

38. Endo, M.; Onoue, Y.; Kuroki, A. Neurotoxin-induced cardiac disorder and its role in the death of fish exposed to Chattonella marina. Mar. Biol. 1992, 112, 371-376. [CrossRef]

39. Nakamura, A.; Okamoto, T.; Komatsu, N.; Ooka, S.; Oda, T.; Ishimatsu, A.; Muramatsu, T. Fish Mucus Stimurates the Generation of Superoxide Anion by Chattonella marina and Heterosigma akashiwo. Fish. Sci. 1998, 64, 866-869. [CrossRef]

40. Shimada, M.; Murakami, T.H.; Imahayashi, T.; Ozaki, H.S.; Toyoshima, T.; Okaichi, T. Effects of sea bloom, Chattonella antiqua, on gill primary lamellae of the young yellowtail, Seriola quinqueradiata. Acta Histochem. Cytochem. 1983, 16, 232-244. [CrossRef]

41. Endo, M.; Sakai, T.; Kuroki, A. Histological and histochemical changes in the gills of the yellowtail Seriola quinqueradiata exposed to the Raphidphycean flagellate Chattonella marina. Mar. Biol. 1985, 87, 193-197. [CrossRef]

42. Ishimatsu, A.; Sameshima, M.; Tamura, A.; Oda, T. Histological Analysis of the Mechanisms of Chattonella-Induced Hypoxemia in Yellowtail. Fish. Sci. 1996, 62, 50-58. [CrossRef]

43. Botana, L.M.; Alfonso, A.; Botana, A.; Vieytes, M.R.; Vale, C.; Vilariño, N.; Louzao, C. Functional assays for marine toxins as an alternative, high-throughput-screening solution to animal tests. TrAC Trends Anal. Chem. 2009, 28, 603-611. [CrossRef]

44. Stewart, I.; McLeod, C. The Laboratory Mouse in Routine Food Safety Testing for Marine Algal Biotoxins and Harmful Algal Bloom Toxin Research: Past, Present and Future. J. AOAC Int. 2014, 97, 356-372. [CrossRef]

45. Manger, R.L.; Leja, L.S.; Lee, S.Y.; Hungerford, J.M.; Wekell, M.M. Tetrazolium-Based Cell Bioassay for Neurotoxins Active on Voltage-Sensitive Sodium Channels: Semiautomated Assay for Saxitoxins, Brevetoxins, and Ciguatoxins. Anal. Biochem. 1993, 214, 190-194. [CrossRef]

46. Ikeda, C.E.; Cochlan, W.P.; Bronicheski, C.M.; Trainer, V.L.; Trick, C.G. The effects of salinity on the cellular permeability and cytotoxicity of Heterosigma akashiwo. J. Phycol. 2016, 52, 745-760. [CrossRef]

47. Dorantes-Aranda, J.J.; Waite, T.D.; Godrant, A.; Rose, A.L.; Tovar, C.D.; Woods, G.M.; Hallegraeff, G.M. Novel application of a fish gill cell line assay to assess ichthyotoxicity of harmful marine microalgae. Harmful Algae 2011, 10, 366-373. [CrossRef]

48. Dorantes-Aranda, J.J.; Nichols, P.D.; Waite, T.D.; Hallegraeff, G.M. Strain variability in fatty acid composition of Chattonella marina (Raphidophyceae) and its relation to differing ichthyotoxicity toward rainbow trout gill cells. J. Phycol. 2013, 49, 427-438. [CrossRef] [PubMed]

49. Dorantes-Aranda, J.J.; Seger, A.; Mardones, J.I.; Nichols, P.D.; Hallegraeff, G.M. Progress in Understanding Algal Bloom-Mediated Fish Kills: The Role of Superoxide Radicals, Phycotoxins and Fatty Acids. PLoS ONE 2015, 10, e0133549. [CrossRef]

50. Žegura, B.; Sedmak, B.; Filipič, M. Microcystin-LR induces oxidative DNA damage in human hepatoma cell line HepG2. Toxicon 2003, 41, 41-48. [CrossRef]

51. Bazin, E.; Mourot, A.; Humpage, A.R. Genotoxicity of a freshwater cyanotoxin, cylindrospermopsin, in two human cell lines: Caco-2 and HepaRG. Environ. Mol. Mutagen. 2009, 51, 251-259. [CrossRef] [PubMed] 
52. McCall, J.R.; Elliott, E.A.; Bourdelais, A.J. A New Cytotoxicity Assay for Brevetoxins Using Fluorescence Microscopy. Mar. Drugs 2014, 12, 4868-4882. [CrossRef]

53. Karathia, H.; Vilaprinyo, E.; Sorribas, A.; Alves, R. Saccharomyces cerevisiae as a Model Organism: A Comparative Study. PLoS ONE 2011, 6, e16015. [CrossRef]

54. Engler, K.H.; Coker, R.; Evans, I.H. A novel colorimetric yeast bioassay for detecting trichothecene mycotoxins. J. Microbiol. Methods 1999, 35, 207-218. [CrossRef]

55. Kuroda, A.; Nakashima, T.; Yamaguchi, K.; Oda, T. Isolation and characterization of light-dependent hemolytic cytotoxin from harmful red tide phytoplankton Chattonella marina. Comp. Biochem. Physiol. Part C Toxicol. Pharmacol. 2005, 141, 297-305. [CrossRef]

56. De Boer, M.K.; Tyl, M.R.; Fu, M.; Kulk, G.; Liebezeit, G.; Tomas, C.R.; Lenzi, A.; Naar, J.; Vrieling, E.G.; van Rijssel, M. Haemolytic activity within the species Fibrocapsa japonica (Raphidophyceae). Harmful Algae 2009, 8, 699-705. [CrossRef]

57. Seger, A.; Dorantes-Aranda, J.J.; Müller, M.N.; Body, A.; Peristyy, A.; Place, A.R.; Park, T.G.; Hallegraeff, G. Mitigating Fish-Killing Prymnesium parvum Algal Blooms in Aquaculture Ponds with Clay: The Importance of $\mathrm{pH}$ and Clay Type. J. Mar. Sci. Eng. 2015, 3, 154-174. [CrossRef]

58. Guillard, R.R.L. Culture of phytoplankton for feeding marine invertebrates. In Culture of Marine Invertebrate Animals; Smith, W.L., Chanley, M.H., Eds.; Plenum Press: New York, NY, USA, 1975; pp. 26-60.

59. Harrison, P.J.; Berges, J.A. Marine Culture Media. In Algal Culturing Techniques; Elsevier BV: Amsterdam, The Netherlands, 2005; pp. 21-33.

60. Lebaron, P.; Catala, P.; Parthuisot, N. Effectiveness of SYTOX Green Stain for Bacterial Viability Assessment. Appl. Environ. Microbiol. 1998, 64, 2697-2700. [CrossRef] [PubMed] 